\title{
Kebijakan Redaksional Radar Banjarmasin pada Pemberitaan Kasus Covid-19 di Kalimantan Selatan
}

\author{
Lalita Hanief, Putri Ayu Hidayatur Rafiqoh, dan Bachruddin Ali Akhmad \\ Fakultas Ilmu Sosial dan Politik, Universitas Lambung Mangkurat \\ lalita_hanief@ulm.ac.id
}

\begin{abstract}
Radar Banjarmasin is one of several local newspapers in South Kalimantan under the JPNN group. Radar Banjarmasin with its tagline "Most Understanding of Region" provides the most current news. When Indonesia was hit by the Covid-19 pandemic, Radar Banjarmasin also reported on this case continuously. This study aims to determine how the editorial policy of print media (Radar Banjarmasin) in reporting the Covid-19 case in South Kalimantan. The research approach used is qualitative with an explanative type. The informants in this study were Mr. Toto Fachrudin as the Editor in Chief, and Mr. Ramli Arisno as the editor. The research results show that the editorial policy of Radar Banjarmasin in reporting the Covid-19 case in South Kalimantan is to focus on the pandemic by continuously monitoring the latest developments in the Covid-19 task force, the results of the Covid-19 test, monitoring hospitals, encouraging the task force to be transparent, and to monitor crowded places. Radar Banjarmasin has made the Covid-19 task force and the Health Service as the main reference, which is in line with Radar Banjarmasin's goal of reporting Covid-19, which is to educate the public, overcome disinformation and hoaxes that are circulating in the community.
\end{abstract}

Keywords: editorial policy; radar banjarmasin; covid-19; printed media; pandemic

\begin{abstract}
Abstrak
Radar Banjarmasin adalah salah satu koran lokal di Kalimantan Selatan di bawah grup JPNN. Radar Banjarmasin dengan tagline 'Paling Paham Soal Banua' menyajikan berita teraktual. Ketika Indonesia dilandai pandemi Covid-19, Radar Banjarmasin juga memberitakan kasus ini secara terus-menerus. Penelitian ini bertujuan untuk mengetahui bagaimana kebijakan redaksional media cetak (Radar Banjarmasin) dalam pemberitaan kasus Covid-19 di Kalimantan Selatan. Pendekatan penelitian yang digunakan yaitu kualitatif dengan tipe eksplanatif. Teknik pengumpulan data berupa wawancara, dokumentasi dan studi literatur. Informan dalam penelitian ini yaitu Toto Fachrudin selaku Pemimpin Redaksi, dan Ramli Arisno selaku redaktur. Hasil penelitian diketahui bahwa kebijakan redaksi Radar Banjarmasin dalam memberitakan kasus Covid-19 di Kalimantan Selatan, adalah fokus pada pandemi dengan terus memantau perkembangan terbaru dari gugus tugas Covid-19, hasil tes Covid-19, pemantauan kepada rumah sakit, mendorong pihak gugus tugas agar terbuka, dan memantau tempat-tempat keramaian. Radar Banjarmasin menjadikan gugus tugas Covid-19 dan Dinas Kesehatan sebagai rujukan utama, dimana hal ini sejalan dengan tujuan Radar Banjarmasin dalam memberitakan Covid-19 yaitu untuk mengedukasi masyarakat, mengatasi disinformasi dan hoax yang banyak beredar di masyarakat.
\end{abstract}

Kata kunci: kebijakan redaksional; radar Banjarmasin; covid-19; media cetak; pandemi

\section{PENDAHULUAN}

Media massa adalah salah satu bentuk komunikasi massa yang efektif. Komunikasi massa sendiri merupakan salah satu level dalam sistem komunikasi. Komunikasi massa seringkali dilakukan oleh sebuah komunikator yang bertujuan untuk memengaruhi khalayak yang jumlahnya besar. Penyampaian pesan disampaikan dengan cara yang bersamaan dan

Korespondensi: Lalita Hanief, S.Sos, M.Si., Fakultas Ilmu Sosial dan Politik Universitas Lambung

Mangkurat, Jl. Brigjen H. Hasan Basri, Pangeran, Kec. Banjarmasin Utara, Kota Banjarmasin, Kalimantan Selatan, 70123, Email: lalita hanief@ulm.ac.id

Menyerahkan: September 2020, Diterima: November 2020, Terbit: Januari 2021

ISSN: 2549-0559 (cetak), ISSN: 2549-1946 (online), Website: http://jurnal.unpad.ac.id/kajian-jurnalisme 
dengan menggunakan media massa. Para pakar komunikasi mendefinisikan komunikasi massa berdasarkan karakteristik yang melekat pada komunikasi massa.

Media massa adalah institusi yang berperan sebagai agent of change, yaitu sebagai institusi pelopor perubahan. Ini adalah paradigma utama media massa. Dalam perspektif budaya, media massa telah menjadi acuan utama untuk menentukan definisi-definisi terhadap suatu perkara, dan media massa memberikan gambaran atas realitas sosial (Morissan, 2010). Menurut Agee, media massa yaitu saluran sebagai alat atau sarana yang dipergunakan dalam proses komunkasi massa. Media massa secara pasti memengaruhi pemikiran dan tindakan khalayak. Budaya, sosial, dan politik di masyarakat dipengaruhi oleh media yang beredar ditengah-tengah mereka. Berdasarkan Shoemaker dan Reese, terdapat beberapa faktor yang berpengaruh terhadap muatan media. Beberapa faktor tersebut antara lain adalah: 1) Faktor individual, yang sangat dipengaruhi oleh faktor pendidikan, pengalaman, kesukuan, agama, gender, dan sikap individu terhadap peristiwa yang dilaporkannya. 2) Faktor rutinitas media, yang terkait dengan rutinitas yang biasa dilakukan media untuk mengolah berita yang masuk dari berbagai pintu berita, termasuk salah satunya dari reporter. 3) Faktor organisasi, yang ditentukan oleh struktur yang ditetapkan oleh pola-pola reguler perilaku yang saling bertautan. 4) Faktor ekstra media yang datang dari luar media, dan, 5) Faktor ideologi yang ditentukan dari kerangka berfikir atau referensi tertentu yang dipakai oleh individu untuk melihat realitas dan bagaimana mereka menghadapinya (Fanani, 2016).

Salah satu media yang dekat dengan masyarakat adalah koran. Koran memiliki karakteristik sebagai media massa cetak dengan kelebihan dan kekurangannya sendiri. Karakteristik koran menurut (Hidayatullah, 2016) yaitu, menggunakan kertas sebagai wadah penyimpanan pesan, disampaikan dengan cara dicetak, bisa dibaca kapan saja dan dimana saja, memerlukan waktu cukup lama (dibanding media elektronik), dan isi pemberitaan dibatasi oleh ruang (space).

Periodisasi koran dicetak adalah harian. Berita yang telah disepakati dalam rapat redaksi akan masuk ke bagian layout pada malam hari. Berita akan naik cetak pada dini haridan disebarkan kepada pembaca pada pagi harinya. Skala koran yaitu lokal, nasional dan internasional. Koran lokal contohnya: Banjarmasin Post, Radar Banjar, Malang Pos dan lainnya. Koran nasional contohnya: Republika, Kompas, Jawa pos. Koran internasional contohnya: The Jakarta Post.

Koran sebagai salah satu bagian dari media massa memiliki peran sebagai media edukasi. Koran menjadi media yang sekaligus mendidik masyarakat agar cerdas, terbuka pikirannya dan menjadi masyarakat yang maju. Koran juga menjadi media informasi, tepatnya media yang menyampaikan informasi setiap hari kepada warga dari informasi yang bersifat lokal, nasional, dan internasional ada dalam lembarannya dengan informasi yang terbuka dan jujur yang telah melewati prosedur pembuatan berita dengan baik dan benar untuk kemudian disampaikan kepada masyarakat. Dengan demikian, maka masyarakat akan menjadi masyarakat yang kaya akan informasi, masyarakat yang terbuka dengan informasi, informatif. Selain itu masyarakat yang kaya akan informasi akan menjadikan masyarakat dapat berpartisipasi dalam berbagai bidang sesuai kemampuannya. Koran disisi lain juga dalam berperan sebagai hiburan. Sebagai agent of change, koran juga dapat menjadi media pewarisan budaya dan katalisator perkembangan budaya. Koran juga secara langsung dapat mempertahankan budaya membaca ditengah masyarakat dengan keberadaannya di fasilitas-fasilitas umum seperti perkantoran, ruang tunggu, dan di jalanan yang sering dibawa oleh para penjual koran.

Radar Banjar adalah salah satu koran lokal terbesar di Kalimantan Selatan. Dikutip dari https://Kalimantan Selatan.prokal.co/, Radar Banjar berdiri sejak 25 januari 2001 dan merupakan jaringan media nasional, Jawa Pos News Network (JPNN). Radar Banjar terbit 24 halaman dengan tiga bagian yaitu halaman utama, Radar Banua dan Radar Sport. Tagline Radar 
136 | Kajian Jurnalisme

Volume 04 Nomor 02 Tahun 2021

DOI: $10.24198 / \mathrm{jkj} . \mathrm{v} 4 \mathrm{i} 2.29354$

Banjar adalah "Paling Paham Soal Banua" yang artinya paling mengerti tentang Kalimantan Selatan.

Radar Banjar menyajikan berita dari skala nasional dan lokal. Berita lokal menjadi kekuatan Radar Banjar untuk menarik minat pembaca. Saat virus Covid-19 pertama kali ditemukan di Wuhan, China pada akhir tahun 2019, Radar Banjar telah turut memberitakannya namun secara parsial. Hal ini diungkapkan Toto Fachrudin selaku Pimpinan Redaksi Radar Banjar.

Covid-19 menjadi isu sentral yang menarik untuk diberitakan karena ditetapkan sebagai pandemi. Kasus Covid-19 di Kalimantan Selatan mengandung nilai berita berupa Impact, karena wabah penyakit ini telah menyebabkan 7 orang meninggal dari 99 kasus (data per 21 april 2020, sumber: IG wargabanua). Tercatat hingga bulan April 2020 di Indonesia telah menyebabkan 535 jiwa meninggal dunia (data tanggal 18 April 2020) (Ramadhan, 2020).

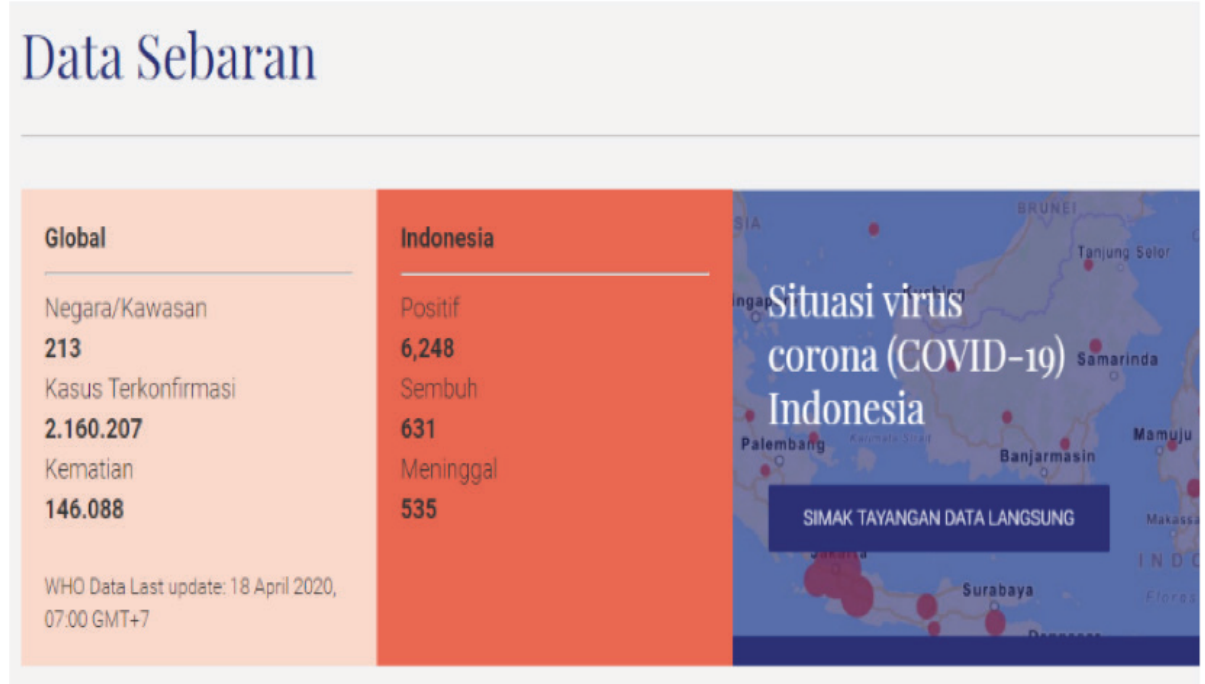

Gambar 1. Kasus covid-19 di Indonesia data per 18 april 2020 Sumber: www.covid19.co.id

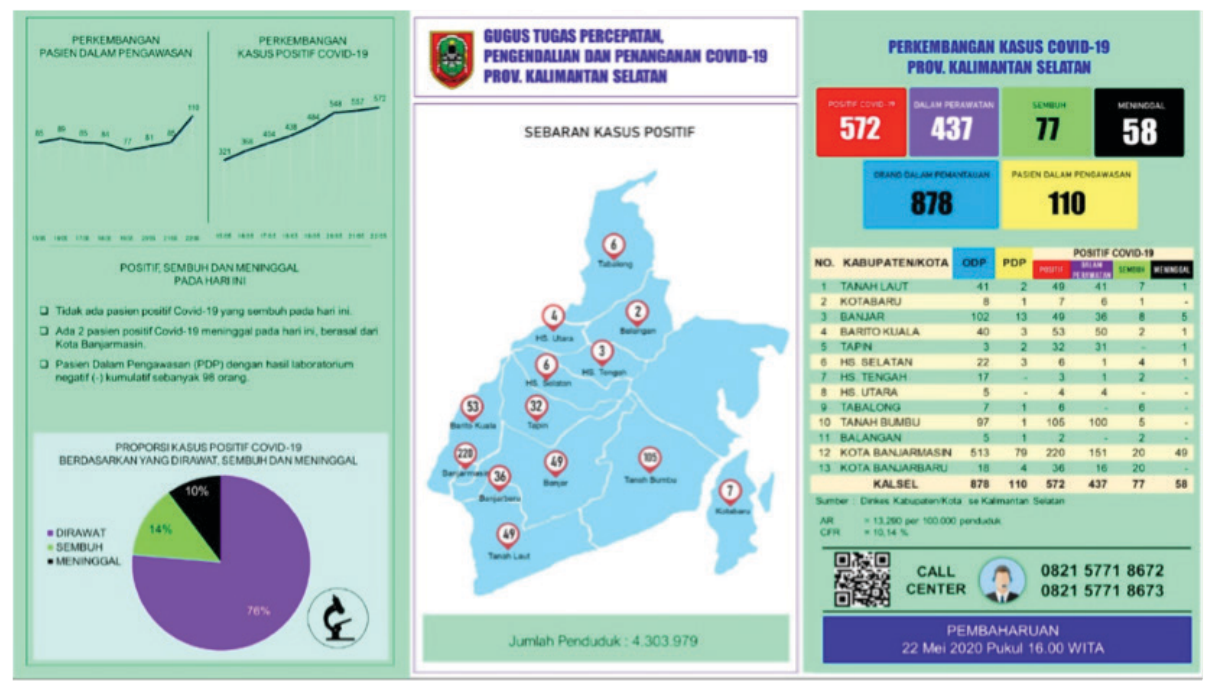

Gambar 2. Data pasien Covid-19 di Kalimantan Selatan per 22 mei 2020 Sumber: dinkes.Kalimantan Selatanprov.go.id 
Menurut Triyaningsih (2020), media terutama media sosial menjadi rujukan bagi masyarakat untuk mendapatkan informasi mengenai virus Covid-19. Adapun efek media kepada masyarakat menunjukkan strong effect bahkan mampu membentuk persepsi masyarakat Pamekasan tentang pencegahan penularan virus Covid-19 kepada individu.

Media massa terus memberitakan kasus Covid-19 hingga saat ini karena mengandung news value impact. Pandemi ini berdampak besar pada kehidupan masyarakat di seluruh dunia. Pemberitaan media massa mengenai kasus Covid-19 dapat menimbulkan ketakukan masyarakat akibat distorsi informasi dan framing media. Berbeda halnya dengan yang dilakukan Republika online yang menyajikan informasi positif mengenai pandemi.

Menurut Astrid (2020), Portal Republika online memberikan informasi positif dengan tagar berita baik. Pada saat beberapa media memberitakan informasi jumlah kematian dan keseraman dari Covid-19, Republika hadir dengan informasi Covid-19 yang memberikan harapan kepada masyarakat untuk tetap dapat optimis melawan pandemi ini. Hal tersebut juga sejalan dengan adanya jurnalisme positif yang berharap memberikan hal-hal yang sifatnya konstruktif dan solutif.

Kebijakan redaksional ditentukan dari lima faktor yaitu faktor individual, organisasional, rutinitas media, ekstra media dan ideologi (Shoemaker \& Vos, 2009). Media cetak koran dalam menentukan sebuah kebijakan redaksional ditentukan lima faktor tersebut. Berita yang dipublikasi melalui koran telah melalui proses panjang mulai dari rapat redaksi, peliputan, penulisan, editing, layout hingga naik cetak dan distribusi kepada pembaca.

Kebijakan redaksional Radar Banjar pada pemberitaan Covid-19 di Kalimantan Selatan penting diteliti karena kasus Covid-19 memberikan dampak besar kepada masyarakat. Dampak kesehatan, ekonomi dan sosial dirasakan masyarakat dengan adanya pandemi Covid-19. Kebijakan redaksional Radar Banjar menjadi penentu bagaimana sebuah kejadian bisa dibingkai dalam berita sehingga memberikan edukasi kepada pembacanya. Penelitian ini berfokus pada masalah bagaimana kebijakan redaksional Radar Banjarmasin dalam pemberitaan kasus Covid-19 di Kalimantan Selatan.

\section{METODE}

Penelitian ini menggunakan pendekatan kualitatif, yang ditujukan untuk mengetahui kebijakan redaksional Radar Banjarmasin dalam pemberitaan kasus Covid-19 di Kalimantan Selatan. Penelitian kualitatif memiliki sifat sempit, khusus dan mendalam. Tipe penelitian yang digunakan yaitu deskriptif. Tipe ini digunakan untuk mendeskripsikan proses kebijakan redaksional Radar Banjar dalam pemberitaan kasus Covid-19 di Kalimantan Selatan, serta faktor-faktor penentu kebijakan redaksional koran. Teknik analisis yang digunakan berupa coding, annotating, memo, lingking, searching dan retreiving, serta displaying. Kemudian objek penelitian ini adalah kebijakan redaksional Radar Banjar. Teknik pengumpulan data berupa wawancara, dokumentasi, studi literatur. Informan dalam penelitian ini yaitu Toto Fachrudin selaku Pemimpin Redaksi, dan Ramli Arisno selaku redaktur.

\section{HASIL DAN PEMBAHASAN}

Radar Banjarmasin adalah salah satu koran lokal harian yang terbit di Kalimantan Selatan sejak 25 Januari 2001. Radar Banjarmasin merupakan bagian dari jaringan media nasional, Jawa Pos News Network dengan induk harian Jawa Pos. Saat ini, Radar Banjarmasin terbit dengan 24 halaman dengan tiga seksi: Halaman Utama, Radar Banua dan Radar Sports. Radar Banjarmasin juga aktif menggelar berbagai kegiatan diskusi dan seminar melalui Radar Banjarmasin Forum. 
138 | Kajian Jurnalisme

Volume 04 Nomor 02 Tahun 2021

DOI: $10.24198 / \mathrm{jkj} . \mathrm{v} 4 \mathrm{i} 2.29354$

Radar Banjarmasin memiliki tagline "Paling Paham Soal Banua" yang artinya paling memahami, mengerti mengenai daerah (Kalimantan Selatan). Radar Banjarmasin mencakup area liputan di Banjarmasin, Banjarbaru, Martapura dan kabupaten lainnya di Kalimantan Selatan. Berdasarkan hasil wawancara kepada Pimpinan Redaksi Radar Banjarmasin, Toto Fachrudin menyatakan bahwa perekrutan wartawan dilakukan secara terbatas dengan syarat pendidikan D3 dan S1 dari berbagai jurusan. Setelah melalui masa magang calon wartawan akan diuji lagi dengan redaktur agar bisa menjadi wartawan tetap.

Rutinitas media ini berupa rapat harian, mingguan dan bulanan. News room berupa grup Whatsapp masing-masing desk. Setiap wartawan wajib membuat perencanaan dan listing berita. Setelah berita terkumpul, maka akan masuk meja redaksi untuk diedit dan dilanjutkan masuk layout. Berita yang sudah $f i x$ akan naik cetak pada tengah malam dan didistribusikan kepada pembaca saat dini hari.

Berdasarkan hasil wawancara dengan pimpinan redaksi Radar Banjarmasin yaitu Toto Fachrudin, dan juga wakil pimpinan redaksi yaitu Helmi, data sekunder berupa dokumentasi dan studi literatur akan dipaparkan dalam hasil penelitian ini. Radar Banjarmasin membuat sebuah kebijakan redaksional berdasarkan faktor-faktor yang dikemukakan Shoemaker dan Reese yaitu: yang pertama adalah faktor individual, dimana faktor ini sangat dipengaruhi oleh berbagai hal lainnya seperti pendidikan seseorang, pengalaman, kesukuan, agama, gender, dan sikap individu terhadap peristiwa yang diliputnya dilapangan, yang kedua yakni faktor rutinitas media yang mana hal tersebut terkait dengan rutinitas yang sering atau kebiasaan yang dilakukan media untuk mengolah berita yang masuk dari berbagai pintu berita, termasuk salah satunya dari reporter. Berikutnya yaitu faktor organisasi, faktor ini merujuk pada polapola reguler perilaku yang saling bertautan, kemudian adanya faktor ekstra media yang timbul dari luar media, dan terakhir yaitu faktor ideologi yang ditentukan dari kerangka berfikir atau referensi tertentu yang di pakai oleh individu untuk melihat realitas dan bagaimana mereka menghadapinya.

Virus Covid-19 pertama kali ditemukan di Wuhan China dan menyebar ke seluruh dunia, termasuk Indonesia. Corona virus disease disebabkan virus Covid-19 yang menyerang saluran nafas hingga dapat menimbulkan kematian. Banyak kasus Covid-19 tercatat di Indonesia dengan angka kematian tinggi. Presiden Joko Widodo secara resmi mengumumkan kepada masyarakat Indonesia tentang adanya kasus pertama kali Covid-19 di Indonesia di Istana Negara tanggal 2 Maret 2020. Dua warga negara Indonesia yang positif Covid-19 tersebut dikabarkan telah mengadakan kontak dengan warga negara Jepang yang datang ke Indonesia. Setelah sebulan lebih sesudah masuknya Covid-19 ke Indonesia, untuk pertama kalinya tercatat angka kesembuhan pengidap Covid-19 yang angkanya lebih besar dari jumlah penduduk yang meninggal karena virus tersebut. Pada tanggal 16 April 2020, data Gugus Tugas Percepatan Penanganan Covid-19 telah menunjukkan 548 pasien yang sembuh, sedangkan jumlah pasien meninggal 496 orang (Baskara, 2020).

Perkembangan virus Covid-19 di Indonesia semakin meningkat setiap harinya. Sejak sebulan dinyatakan resmi muncul di Indonesia, jumlah kasus pengidap virus Covid-19 di Indonesia telah mencapai di atas 5.500 kasus. Media massa kemudian berbondong-bondong memberikan informasi setiap harinya terkait perkembangan virus Covid-19, baik media nasional maupun lokal. Terlebih sejak pemerintah Indonesia menetapkan Pembatasan Sosial Berskala Besar (PSBB) untuk meredam persebaran penyakit ini. Media massa memiliki peran besar dalam hal mengkampanyekan hidup lebih bersih dan melakukan protokol kesehatan di era new normal. Setelah masuk ke Indonesia, Provinsi Kalimantan Selatan pun tidak luput dari penyakit corona yang diketahui disebarkan dari klaster Gowa (jamaah tabligh akbar di 
Gowa, Sulawesi). Bahkan Ibukota Kalimantan Selatan, yaitu Kota Banjarmasin sempat dinyatakan sebagai zona merah karena menjadi penyumbang pasien positif Corona terbanyak di Indonesia. Corona menjadi perhatian sangat penting bagi publik karena berdampak pada lumpuhnya ekonomi, pendidikan, perubahan sosial, kesehatan dan keagamaan di wilayah Kalimantan Selatan. Penerapan PSBB juga sempat dilakukan oleh pemerintah setempat untuk mengurangi penyebaran virus Corona. Media massa kemudian memilik peran sangat penting dalam memberikan informasi kepada masyarakat untuk sadar terhadap kondisi saat ini.

Radar Banjarmasin sebagai media cetak lokal, telah memberitakan Corona sejak awal kasus ini muncul di China dan menyebar ke negara lain.

"Kita mulai memberitakan secara parsial waktu dulu isu Corona belum menjadi isu sentral secara Nasional. Di Indonesia belum ada kasusnya waktu itu, masih banyak kasus-kasus di luar negeri, tetapi itu sudah menjadi atensi. Kita trus monitor bagaimana kasus ini perkebangannya di Indonesia secara umum dan di Kalimantan. Tetapi kita memang punya kebijakan redaksi di radar Banjarmasin sesuai taglinenya 'paling paham soal banua'. Jadi kita lebih banyak memfokuskan konten pemberitaan bicara pada isuisu Kalimantan Selatan baik sosial politik ekonomi yang kita asumsikan isu itu menjadi isu publik yang memiliki pengaruh luas di masyarakat. Itu yang mendasari kenapa kemudian di awal-awal Corona merebak secara global belum ada di sini apalagi di Kalimantan Selatan isu kita giring secara parsial, tidak menjadi konten yang kemudian harus di blow up setiap hari untuk dimonitor. Karena belum ada kasus yang mencuat waktu itu kita hanya tanya bagaimana persiapan, monitor kasus nasional, fokus dan banyak bicara tentang isu-isu politik karena tentang pilkada masih cukup hangat, nah ketika kasus ini mulai mencuat dan pemerintah menyatakan ada kasus Corona di Indonesia nah itu menjadi suatu perhatian juga kita biasa monitor berita-berita secara nasional kita punya JPNN Jawapos Grup. (Fachrudin, Wawancara. 19 Maret 2020).

Kebijakan redaksional Radar Banjarmasin dalam memberitakan kasus Corona di Kalimantan Selatan tentu mempertimbangkan news value. Pamdemi Covid-19 ini menyebabkan dampak luar biasa dalam berbagai aspek kehidupan. Pembaca akan tertarik mencari tahu kabar terbaru mengenai kasus corona di Kalimantan Selatan, bahkan hingga bulan Juni 2020 kasus corona semakin meningkat. Hal ini mengkhawatirkan karena masyarakat akan merasa tidak aman saat beraktivitas di luar rumah. Seperti yang dijelaskan Toto Fachrudin, bahwa mereka mengejar kejujuran pemerintah mengenai data dan penanganan Corona di Kalimantan Selatan.

"News value, pertama yang kita kejar kejujuran pemerintah, transparan kepada publik. Transparansi kejujuran menjadi hal yang sangat penting untuk menghadapi situasi kegaduhan ketidakjelasan kesimpangsiuran hal-hal yang menyangkut corona karena isu bisa menjadi liar masyarakat tidak memiliki edukasi yang baik. Wacana yang beredar di medsos, mestinya pemerintah terbuka terkait dengan masalah corona ada kasus dimana historisnya, misal ada 1 pasien meninggal, dimana kerja dan tinggal, langkah apa yang sudah dilakukan ini penting dilakukan agar masyarakat merasa ada jaminan keamanan jaminan bahwa pemerintah Kalimantan Selatan sudah bergerak cepat melakukan langkah antisipatif, langkah medis, kita mengejar kejujuran" (Fachrudin, Wawancara. 19 Maret 2020).

Toto mendukung keputusan pemerintah untuk meliburkan sekolah untuk memutus mata rantai penyebaran Covid-19. Radar Banjarmasin menjadi wadah sebagai sosialisasi bahwa libur sekolah bukan berarti memanfaatkan waktu untuk melakukan kegiatan diluar rumah, justru adalah untuk menekan laju perkembangan pasien positif corona dengan tetap berada dirumah saja. Radar Banjarmasin memegang teguh kode etik jurnalistik dalam setiap keputusan redaksinya dan sebagai media cetak ingin mengedukasi masyarakat, seperti pernyataan berikut:

"Keputusan meliburkan sekolah adalah tepat untuk memutus mata rantai, kita mendukung. Keputusan pemerintah kita dukung supaya masyarakat tinggal di rumah saja.Tidak kemudian memanfaatkan momentum liburnya ini untuk mencari hiburan 
140 | Kajian Jurnalisme

Volume 04 Nomor 02 Tahun 2021

DOI: $10.24198 / \mathrm{jkj} . \mathrm{v} 4 \mathrm{i} 2.29354$

atau refreshing karena memang tanggungjawabnya memberikan edukasi sebagai media. Nah di satu sisi kita juga mengejar ketika kasus ini sdh muncul di Kalimantan Selatan, pemerintah harus komitmen memberikan informasi kepada publik. Radar Banjarmasin secara kebijakan redaksional berpegang teguh pada kode etik, kemudian berpegang pada narasumber yang menjadi sumber resmi yang kita percaya. Tidak mau menjadikan sumber lain sebagai isu, karena itu kita menjadikan gugus tugas penanganan Covid-19 ketuanya Kepala Dinas Kesehatan. Kemudian leading sector-nya adalah RS Ulin yang menjadi rujukan, ini kita dorong terus agar mereka terbuka. Kalo perlu melakukan jumpa pers tiap hari melaporkan perkembangan-perkembangan karena pers sebagai jembatan informasi yang bisa dipercaya dan diyakini kebenaran kredibilitas informasinya karena itu kita mendorong kita sampaikan itu secara langsung kepada gugus tugas untuk bisa terbuka entah melalui jumpa pers atau terbuka saat dikonfirmasi wartawan, selalu open mind dan segala macem" (Fachrudin, Wawancara. 19 Maret 2020).

Tujuan Radar Banjarmasin memberitakan kasus Corona adalah untuk mengedukasi masyarakat. Selain itu, untuk mengatasi disinformasi dan hoax yang banyak beredar di media sosial yang justru membuat kepanikan di sejumlah pihak. Dalam hal ini, Radar Banjarmasin berperan dalam memberikan informasi yang tidak hanya terbarukan, tetapi juga informasi yang benar. Berikut pernyataan Pimred Radar Banjarmasin:

"Ini permasalahan serius. Kita selalu menjadikan isu ini di running setiap hari sampai sejauh mana. Step-step yang telah dilakukan pemerintah. Kemudian bagaimana langkah taktis teknis antisipatif. Ini perlu disampaikan kepada publik. Di tengah merebaknya informasi isu liar hoax dan segala macam, yang itu menjadi sumber informasi masyarakat seperti media sosial apapun platform nya nah justru harus ada keberimbangan dari informasi yang bisa dipertanggungjawabkan. Media menjembatani, yang ingin kita sampaikan kepada publik adalah bahwa dalam hal ini jangan panik. Kita memberikan edukasi. Jangan berlebihan menyikapi sampai kemudian menyebarkan isu yang tidak bertanggungjawab tetapi tentunya media tidak bisa memberikan informasi yang dapat dipertanggungjawabkan kalau sumbernya sendiri tidak serius untuk memberikan informasi secara terbuka karena itu kita terus mendorong. Karena transparansi, keterbukaan dan kejujuran itu menjadi kunci penting ketika ada disinformasi yang bisa membuat bias karena itu informasi tandingan yang bisa didapatkan dari platform di luar sumber-sumber resmi". (Fachrudin, Wawancara. 19 Maret 2020).

Toto Fachrudin menjelaskan bahwa untuk menjadi wartawan Radar Banjarmasin minimal harus berpendidikan Strata 1 atau minim Diploma 3. "Kita pernah nyoba SMA ternyata kompetensi keilmuan pengetahuan dan wawasan tidak bisa mencukupi untuk standar itu. Wartawan, redaktur dan layouter terdiri dari laki-laki dan perempuan. Semua orang mempunyai kesempatan yang sama untuk menjadi wartawan tetap, dengan melalui proses seleksi lalu menjadi wartawan magang.

"Semua calon wartawan kita rekrut tidak dengan cara terbuka. Kita pernah mencoba berbagai mekanisme rekrutmen wartawan. Ternyata memang mendapatkan jurnalis bagus sesuai standar kami itu sangat sulit di Kalimantan Selatan. Memang ada beberapa perguruan tinggi yang punya jurusan komunikasi tapi tidak juga menjamin lulusan itu siap, berdasarkan pertimbangan itu, 8 tahun yang lalu, dalam perekrutan kita membuka sekolah jurnalistik. Kita membuka short course jurnalistik bagi mahasiswa semester akhir atau fresh graduate yang ingin mengetahui dunia jurnalistik. Syaratnya biasa ada rentang usia 24 atau 25 maksimal, bisa mahasiswa semester akhir berbagai latar belakang keilmuan dan wajib mengirimkan karya tulis mereka. Nah dari situ kita seleksi mana yang cukup bagus dan layak itu yang kita ambil. Nanti mereka tergabung dalam pelatihan, ada yang 2 minggu, ada yang 1 minggu full. Kami melihat kualitas bukan kuantitas, nanti dirangking, redaktur yang memberi tugas dan menilai. Dengan sistim rolling misal 1 minggu di desk ekonomi, politik dan seterusnya, lalu dinilai. Kalau mau ikut bergabung, maka akan menjadi wartawan magang. Paling lama 9 bulan sudah menjadi wartawan tetap" (Fachrudin, Wawancara. 19 Maret 2020).

Rutinitas media cetak berupa rapat yang dilakukan secara rutin harian, mingguan dan 
bulanan. Dulu rapat dilakukan secara tatap muka untuk mengagendakan isu-isu apa yang akan di garap, namun sekarang setelah adanya media sosial maka rapat dapat melalui media Whatsapp. Sehingga news room bisa dilakukan dimana saja dan kapan saja koordinasi dilakukan melalui grup WA masing-masing desk untuk memudahkan komunikasi tanpa tatap muka. Pimred megawasi jalannya tugas wartawan secara keseluruhan seperti pejelasan Toto Fachrudin berikut ini:

"Kita punya news room melalui whatsapp grup. Dulu sebelum ada medsos kita rapat untuk mengagendakan isu-isu apa yang akan kita garap, dalam 1 bulan running newsnya isu apa yang mau kita angkat. Ada rapat harian mingguan bulanan. Tapi sekarang setelah ada platform whatsapp grup maka semuanya kita manfaatkan perangkat itu, jadi dalam hal kebijakan redaksional menentukan kebijakan redaksi itu biasanya kita ada WA grup redaktur, kita discuss mana yang paling kuat unsur news value nya informasi publiknya. Itu bisa politik, sosial ekonomi, kebijakan publik dsb. Nah karena sekarang lagi kasus Corona, jadi kita lebih fokus ke Corona. Isu yg kita diskusikan adalah apa yang harus kita lakukan, pemberitaan apa yang mau kita sampaikan, baru kemudian ada penugasan setiap hari khusus untuk halaman 1 itu penanggungjawabnya Redpel tapi tetap di bawah pengawasan saya sebagai Pemred. Redpel melakukan perencanaan, ini sudah dibuat malam hari, seperti hari ini wartawan sudah tahu, eh kamu ke sana, kamu ke sini. Di desk halaman 1 itu ada 2 wartawan, 1 di Banjarmasin 1 di Banjarbaru karena ini 2 kota liputan yang biasanya menjadi sumber informasi secara geografis. Kalo di daerah kita memanfaatkan wartawan daerah, kemudian kita tugaskan setiap hari menggarap isu-isu yg penting misalnya hari ini tadi kita akan monitor bagaimana update terbaru dari gugus tugas Covid. Bagaimana hasil tes dari 5 pasien yang masuk ke pengawasan. Apa yg dilakukan rumah sakit agar hasil cepat diketahui, karena semua menunggu dari pusat. Kita juga meminta wartawan untuk mendorong pihak gugus tugas harus terbuka terus apapun informasinya itu, kemudian kita meminta wartawan yang di Banjarmasin untuk melihat stok darah di PMI, biasanya dengan adanya kasus ini orang jadi ragu untuk mendonorkan, kita minta wartawan juga pantau tempat keramaian contoh di mall. Kita mau melihat publik ini benar-benar mengikuti nggak itu bisa menjadi parameter kepatuhan publik" (Fachrudin, Wawancara. 19 Maret 2020).

Selain rapat rutin untuk semua redaktur dan wartawan, tugas wartawan yaitu melakukan perencanaan, listing berita dan untuk proses penentuan headline maksimal jam 10 malam. Toto Fachrudin menjelaskan bahwa wartawan Radar Banjarmasin memiliki beberapa kewajiban yang harus dilakukan pada setiap hari yaitu, (1) Perencanaan (2) Listing berita semuanya. Untuk desk halaman 1, penugasan langsung dari redaktur pelaksana dan pimpinan redaksi, untuk wartawan masing-masing desk. Halaman 1 Metropolis harus melakukan setiap hari. Apa yang akan mereka tulis sudah di-listing mulai jam 2 siang maksimal jam 4. Misalnya ada 3 wartawan, misal wartawan A bercerita dalam grupnya, saya sudah mendapatkan berita ABCD, yang lainnya juga, lalu berdasarkan percakapan tersebut, redaktur bisa melihat dan menentukan fotonya apa dalam perencanaan itu, lalu wartawan harus menulis beritanya apa, narasumbernya siapa, fotonya ada tidak dan diberikan lead 1 alinea. Dengan demikian, maka semua redaktur bisa melihat siapa yang paling kuat news value nya untuk bisa dijadikan headline. Jadi sudah tahu mana yang jadi headline, berita tengah dan pinggiran. Itu semua diproses sampai jadi berita. Pada malam hari tepatnya pukul 6 sampai jam 9 maksimal jam 10, wartawan wajib membuat listing berita. Di sebarkan lagi di grup, masing-masing desk mempunyai grup. Ada metropolis, sport, ekonomi, dan lain-lain. Masing-masing akan listing, untuk mencari topik pada keesokan harinya. Kalau mereka tidak melakukan itu, itu dijadikan sebagai absensi. Dalam hal ini, absensi dilihat sebagai office hour untuk admin, dan kantoran, tapi untuk wartawan tidak wajib untuk absen sidik jari. Tetapi perencanaan dengan listing menjadi ganti absensi, maka jika tidak membuat maka akan didenda potong uang makan.

Toto memaparkan bahwa ada notulen oleh wakil redaktur pelaksana yang akan merangkum yang di Banjarmasin dan Banjarbaru untuk kemudian dibagikan di grup bersama. 
142 | Kajian Jurnalisme

Volume 04 Nomor 02 Tahun 2021

DOI: $10.24198 / \mathrm{jkj} . \mathrm{v} 4 \mathrm{i} 2.29354$

Ini semua wartawan redaktur semuanya. Lalu ada grup redaktur, ada grup masing-masing desk, grup zona wilayah. Nanti dinotulensi dengan wakil pimpinan redaksi dan bisa dilihat bahwa, redaktur pelaksana memiliki kuasa untuk menarik berita. Setelah itu, kemudian dapat diperdalam, dibuat multi angle fotonya. Semua yang muncul ini by design dan by concept. Kemudian ada design grafis, layout yang melihat apakah terdapat data yang dapat diolah. Wartawan di halaman 1 memiliki grade yang sudah tinggi, karena wartawan tersebut sudah memahami bagaimana membuat angle berita yang menarik, serta minim dalam membuat kesalahan teknis. Berdasarkan kebijakan dari Radar Banjarmasin, apabila melakukan kesalahan salah ketik, maka akan didenda sebesar 3 ribu. Denda juga akan diberlakukan jika wartawan tidak memenuhi deadline.

Terkait faktor ekstra media, Toto mengakui bahwa "ya pasti ada pengaruh, tidak ada media yang tidak terpengaruh dengan kepentingan-kepentingan di luar kebijakan redaksi. Ada faktor-faktor yang memengaruhi hal tersebut. Sebagai pemimpin redaksi saya merasakan itu. Tetapi sebisa mungkin ranah-ranah kebijakan redaksi itu tidak boleh diinterfensi. Kalaupun ada interfensi dalam batas yang bisa dikompromikan". Radar Banjarmasin memiliki kekhasan dalam menetapkan kebijakan redaksi yang membedakan dengan media cetak lainnya, yaitu terdapat pada faktor individual, faktor rutinitas media, faktor organisasi, faktor ekstra media yang datang dari luar media, dan faktor ideologi.

Terkait kebijakan redaksional dalam pemberitaan kasus Covid-19 di Kalimantan Selatan berdasarkan faktor individual, wartawan di Radar Banjarmasin tidak diharuskan memiliki latar pendidikan jurnalistik, namun disyaratkan minimal D3 dan S1. Strata pendidikan tersebut dinilai mampu secara kognitif untuk menjadi seorang jurnalis. Meskipun proses rekrutmen wartawan hanya berdasarkan latar belakang pendidikan dan tidak berdasarkan pengalaman jurnalistik dapat menyebabkan mobilitas keluar masuk posisi wartawan sangat tinggi (Wildan, Saleh, \& Imron, 2020). Namun Radar Banjarmasin seringkali melakukan pelatihan jurnalistik kepada setiap calon wartawan. Dalam prosesnya, calon wartawan akan magang selama 3 bulan, lalu diseleksi kembali untuk menjadi wartawan tetap. Dari segi jenis kelamin para wartawan, layouter dan redaktur mayoritas laki-laki, namun ada juga perempuan. Hal ini sesuai dengan yang dikemukakan Rahman mengenai profesi seorang wartawan yang tentunya melalui berbagai tahapan, setelah tahap rekrutmen, maka jurnalis akan bekerja sebagai reporter magang, jika dinilai mampu menulis dan meliput dengan baik maka selanjutnya akan menjadi wartawan tetap (Rahman, 2010).

Faktor rutinitas media menjadi penentu sebuah kebijakan redaksional dibuat. Radar Banjarmasin rutin melakukan rapat melalui media whatsapp untuk menentukan perencanaan, listing dan penentuan headline dan sebagainya. Maksimal jam 10 malam batas untuk finishing berita hingga bisa masuk meja layouter dan selanjutnya siap naik cetak hingga distribusi. Faktor organisasi menentukan bagaimana proses rekrutmen calon wartawan, hingga cara kerja wartawan di media cetak. Sistem punishment diterapkan saat wartawan melakukan kesalahan pengetikan kata dengan memotong uang makan sebesar 3 ribu rupiah per kesalahan, dan jika tidak melakukan listing. Penghargaan akan diberikan jika wartawan mampu mengumpulkan poin saat kinerjanya melampaui target, misalnya berita yang ditulis akan dimuat pada headline. Faktor ekstra media dari Radar Banjarmasin memiliki peran dalam penentuan kebijakan redaksional namun tidak untuk menjadikan berita berpihak. Kejujuran dan menjujung kode etik sangat dijaga oleh Radar Banjarmasin. Sponshorship sesuai dengan konsep bisnis, namun pemberitaan jujur yang tidak menyakiti. Tidak ada media yang tidak terpengaruh dengan kepentingan-kepentingan di luar kebijakan redaksi. Ada faktor-faktor yang memengaruhi itu. Tetapi sebisa mungkin ranah-ranah kebijakan redaksi itu tidak boleh diinterfensi. Kalaupun 
ada interfensi, tetap dalam batas yang bisa dikompromikan. Faktor ideologi Radar Banjarmasin berpegang pada prinsip kebenaran, fakta dan kejujuran. Radar Banjarmasin tidak memiliki orientasi politik terhadap salah satu kepentingan politik, tidak berafiliasi pada kepentingan bisnis, tidak juga berprinsip pada ideologis religius, pastinya tidak memuaskan, baik dari diksi, arah pemberitaan, angle berita, framing dan hal lainnya.

Radar Banjarmasin memenuhi beberapa fungsi komunikasi massa. Nurudin (2007) mengemukakan bahwa fungsi komunikasi massa secara khusus yaitu: fungsi informasi, fungsi mendidik (to educate), fungsi persuasi (to persuade), dan fungsi hiburan. Fungsi informasi dipenuhi dengan fungsi meyakinkan yaitu melalui berita kasus Corona, Radar Banjarmasin berupaya meyakinkan masyarakat untuk taat pada himbauan pemerintah dengan berdiam di rumah. Upaya tersebut untuk memutus mata rantai penyebaran virus Covid-19. Narasumber yang dipilih tentu yang kredibel, sesuai dengan keahlian dan wewenang untuk menyampaikan informasi yang diulas dalam berita. Kelengkapan unsur berita $5 \mathrm{~W} 1 \mathrm{H}$ juga penting agar masyarakat yakin dengan berita yang dibacanya. Ini juga sebagai upaya mengatasi hoax yang beredar di media sosial.

Menurut Nurudin ada beberapa karakteristik dari media massa yaitu: komunikator terlembaga, dengan menggunakan media massa yang berbentuk suatu perangkat yang modern, proses penyampaian pesan pada komunikasi massa melibatkan banyak pihak didalamnya sehingga komunikator dalam komunikasi massa bersifat lembaga, yakni suatu institusi atau organisasi. Pesan komunikasi massa bersifat umum. Artinya siapapun boleh mendapatkan pesan yang disampaikan melalui media massa. Media massa hanya menyebarkan informasi yang sesuai dengan kriteria yaitu pesan atau informasi yang disampaikan harus penting, menarik dan berguna demi kepentingan umum. Komunikannya heterogen dan anonim karena daya jangkaunya yang sangat luas. Kemudian, keserempakan dalam penerimaan pesan, maksudnya adalah bahwa komunikan menerima informasi atau satu pesan dalam satu waktu yang bersamaan meskipun mereka ada pada tempat yang berbeda. Selanjutnya, komunikasi massa bersifat satu arah, dengan menggunakan media massa maka komunikator dan komunikan tidak dapat melakukan kontak langsung. Dengan demikian, maka dalam komunikasi massa tidak terjadi pengendalian arus informasi. Terakhir yaitu feedback tertunda (delayed), karena massa memiliki sifat pesan komunikasi yang satu arah, maka komunikan secara umum tidak dapat secara langsung memberikan umpan balik (feedback) pada komunikator. Sehingga dengan adanya hal tersebut, media massa diharuskan memiliki perencanaan dan persiapan yang baik sehingga pesan maupun informasi yang disampaikan kepada komunikan menjadi lebih komunikatif.

Radar Banjarmasin sebagai media cetak lokal memiliki karakteristik dari media massa yaitu komunikator terlembaga yang terdiri dari kumpulan pelaku pers yang bernaung dalam institusi pers. Ada pemimpon redaksi, redaktur pelaksana, wakil redaktur pelaksana, redaktur, editor, wartawan, fotografer, layoter serta departemen iklan. Pesan yang disampaikan juga bersifat umum, ditujukan kepada semua kalangan. Pemberitaan tentang Corona di Kalimantan Selatan disajikan kepada semua masyarakat karena mengandung kepentingan publik. Saragih (2016) menyebutkan bahwa manajemen redaksi harus mampu mengatur dan mengarahkan seluruh elemen yang ada di dalamnya, termasuk wartawan untuk menjalankan fungsinya dengan efisien dan efektif. Masyarakat memerlukan informasi yang terpercaya untuk mengatasi disinformasi berita hoax yang ada di media sosial. Untuk itulah, Radar Banjarmasin berusaha untuk menyajikan berita terkait Covid-19 dengan jelas dan terang agar tidak menimbulkan kesalahpahaman oleh para pembaca. Media massa adalah institusi yang berperan sebagai agent of change, yaitu sebagai institusi yang mempelopori sebuah perubahan di masyarakat. Ini 
144 | Kajian Jurnalisme

Volume 04 Nomor 02 Tahun 2021

DOI: $10.24198 / \mathrm{jkj} . \mathrm{v} 4 \mathrm{i} 2.29354$

adalah paradigma utama media massa. Berita ataupun informasi yang disampaikan hendaknya memiliki pesan yang tidak menyesatkan, karena berpengaruh pada pola pikir masyarakat (Bungin, 2019).

Komunikan dari Radar Banjarmasin bersifat heterogen, anonim dan terpisah secara fisik. Heterogen dalam hal latar pendidikan, budaya, usia dan lainnya, anonim karena tidak saling mengenal antara pembaca. Pesan yang disampaikan Radar Banjarmasin bersifat serempak karena koran dipublikasi secara bersamaan menuju penjuru Kalimantan Selatan. Komunikasi dalam media cetak bersifat satu arah, feedback akan tertunda sebab pembaca tidak bertatap muka dengan lembaga pers sebagai komunikator. Namun pembaca memiliki kesempatan untuk memberikan masukan dan saran untuk perkembangan kualitas koran Radar Banjarmasin. Sebagaimana yang disampaikan oleh Hiebert, bahwa audience cenderung bersifat secara heterogen. Audience adalah mereka yang berasal dari berbagai lapisan dan kategori sosial (Hiebert \& Gibbons, 2017). Beberapa media tertentu mempunyai sasaran, tetapi heterogenitasnya juga tetap ada. Seperti Radar Banjarmasin yang tentunya memiliki sasaran yaitu audience wilayah Kalimantan Selatan, namun pembaca juga berpotensi besar dari berbagai wilayah dan kalangan.

Pemberitaan kasus Covid-19 di Kalimantan Selatan sangat penting diketahui masyarakat dan menjadi perhatian publik. Perkembangan kasus Corona dimulai bulan Maret hingga Juni ini semakin mengkhawatirkan. Pasien semakin bertambah walaupun Banjarmasin, Banjarbaru dan Kabupaten Banjar telah menerapkan Pembatasan Sosial Berskala Besar (PSBB), namu pada kenyataannya tidak berpengaruh secara signifikan. Masyarakat memerlukan edukasi terkait menghadapi pandemi Covid-19 misalnya dengan pola hidup sehat, menggunakan masker, menjaga jarak, berdiam di rumah dan menjaga kesehatan. Koran radar Banjarmasin bertujuan mengedukasi masyarakat melalui pemberitaannya dengan menyajikan data-data dari sumber yang kredibel.

News value yang terkandung dalam pemberitaan Corona di Kalimantan Selatan pada koran Radar Banjarmasin yaitu Impact, memiliki pengaruh yang kuat dalam memberikan informasi kepada khalayak luas. Kebaruan, yaitu mengutamakan pada nilai berita yang mutakhir, up to date, terbarukan, sehingga masyarakat tetap mendapatkan informasi yang teranyar tentang perkembangan kasus Covid-19 baik itu di Kalimantan Selatan sendiri maupun di Indonesia, dan dunia pada umumnya. Proximity, yaitu dekat dengan masyarakat, sesuai dengan motto dari Radar Banjarmasin itu sendiri, yakni "Paling Paham Soal Banua", Radar Banjarmasin berusaha untuk tetap berada ditengah-tengah masyarakat untuk terus menjadi pendamping khalayak dalam menghadapi kasus Corona. Yang terakhir yaitu Human Interest, yakni ketertarikan pada aktivitas manusia, dalam hal ini Radar Banjarmasin berusaha untuk terus menginformasikan tentang hal apa saja mengenai Covid-19 berkaitan dengan kepentingan masyarakat luas. Secara harfiah, news value atau nilai berita adalah patokan wartawan dalam menilai apakah sebuah peristiwa layak diberitakan atau tidak (Komunikasipraktis.com, 2013). Pandemi Covid-19 hingga saat ini telah memiliki dampak yang cukup besar pada sektor ekonomi, pendidikan, sosial, budaya dan keagamaan. Banyaknya isu yang simpang siur ditengah masyarakat tentang adaptasi new normal saat ini membuat berbagai pihak merasa panik tentang kondisi perekonomian. Kemudian pendidikan yang diharuskan secara online, dan kewajiban menggunakan masker di segala tempat. Media massa tentunya memiliki peran besar dalam hal penyampaian informasi yang layak, memberikan ketenangan kepada masyarakat dalam situasi yang genting seperti saat ini, dan sekaligus memberikan solusi bagi masyarakat yang terdampak Covid-19 di Kalimantan Selatan. Peran media massa pada kondisi saat ini tentunya diharapkan berujung pada perubahan perilaku di masyarakat dalam hal menyikapi 
situasi pandemi. Pada masa saat ini, hal yang penting tidak hanya terpusat pada kesadaran terhadap konteks kesehatan, tetapi juga bagaimana mengubah perilaku dan tetap berfokus untuk membangun persepsi masyarakat dari sisi kultur atau budaya dan sosial ("Peran Media Massa Ubah Perilaku Masyarakat dalam Menyikapi Pandemi”, 2020).

Media massa merupakan pekerjaan yang benar-benar memerlukan keahlian, memerlukan manajemen yang baik dan tertata, media massa dipandang berkekuatan besar dalam memengaruhi masyarakat karena sifat dan faktanya bahwa pekerjaan media massa adalah menceritakan peristiwa, maka kesibukan utama media massa adalah mengkonstruksikan berbagai realitas yang akan disiarkan kepada khalayak (Triyaningsih, 2020). Dengan demikian, maka harus ada individu yang bergerak dalam struktur yang menjamin kontinuitas dan kerjasama, serta unsur $5 \mathrm{~W} 1 \mathrm{H}$ selalu menjadi syarat utama dalam penulisan berita dan harus cover both sides, karena hal ini bertujuan agar berita yang disampaikan mencakup keseluruhan dan tidak berada pada pemberitaan yang setengah-setengah.

\section{SIMPULAN}

Berdasarkan hasil penelitian, dapat ditarik kesimpulan bahwa pemberitaan yang dimuat oleh Radar Banjarmasin berdasarkan pada faktor-faktor penentu kebijakan redaksional yaitu individual, rutinitas media, organisasi, ekstra media dan ideologi memberitakan kasus Corona di Kalimantan Selatan.

Hasil penelitian menujukkan bahwa faktor-faktor penentu ada dalam kebijakan redaksi Radar Banjarmasin dalam memberitakan kasus Corona di Kalimantan Selatan, yaitu faktor individual dari wartawan dan tim redaksi berupa latar pendidikan. Kemudian adanya faktor organisasi bahwa terdapat struktur yang jelas di Radar Banjarmasin disertai jobdesk pada masingmasing karyawan. Kemudian adanya faktor rutinitas media berupa news room baik melalui grup Whatsapp maupun tatap muka untuk membahas rencana peliputan berita, listing hingga laporan berita yang telah ditulis hingga evaluasi. Yang terakhir yakni faktor ekstra media yaitu pengiklan, pemilik media dan pemerintah yang memengaruhi sebuah kebijakan redaksional dan ideologi dari Radar Banjarmasin. Hasil penelitian diketahui pula tentang kebijakan redaksi Radar Banjarmasin selama kasus Covid-19 berlangsung di Kalimantan Selatan, yaitu mereka terus berfokus pada pandemi ini dengan terus memantau perkembangan terbaru dari Gugus Tugas Covid-19, hasil tes Covid-19, pemantauan kepada rumah sakit, mendorong pihak gugus tugas agar terbuka, memantau tempat-tempat keramaian. Radar Banjarmasin menjadikan gugus tugas Covid-19 dan Dinas Kesehatan sebagai rujukan utama yang mana hal ini sejalan dengan tujuan Radar Banjarmasin dalam memberitakan Covid-19 adalah untuk mengedukasi masyarakat, mengatasi disinformasi dan hoax yang banyak beredar di masyarakat.

\section{DAFTAR PUSTAKA}

Astrid, A. F. (2020). Jurnalisme Positif Ala Portal Republika Pada Isu Covid-19. Jurnal Mercusuar, 1(1), 150-161.

Baskara, B. (2020, April 18). Rangkaian Peristiwa Pertama Covid-19. Diakses dari https:// bebas.kompas.id/baca/riset/2020/04/18/rangkaian-peristiwa-pertama-covid-19/.

Bungin, B. (2019). Sosiologi komunikasi. Jakarta: Kencana.

Fanani, F. (2016). Analisis Kebijakan Redaksional Harian Republika pada Pemberitaan ReligioPolitik Masa Kampanye Presiden Tahun 2009. Jurnal The Messenger, 3(2). http://dx.doi. org/10.26623/themessenger.v3i2.269

Hidayatullah, A. (2016). Jurnalisme Cetak (Konsep dan Praktik). Yogyakarta: Buku Litera. Hiebert, R. A., \& Gibbons, S. (2017). Exploring mass media for a changing world. Abingdon: 
146 | Kajian Jurnalisme

Volume 04 Nomor 02 Tahun 2021

DOI: $10.24198 / \mathrm{jkj} . \mathrm{v} 4 \mathrm{i} 2.29354$

Routledge.

Komunikasipraktis.com. (2013, May 6). 10 Nilai Berita (News Values). Diakses dari https:// www.komunikasipraktis.com/2013/05/10-nilai-berita-news-values.html.

Morissan, M. A. (2010). Jurnalistik Televisi Mutakhir. Jakarta: Kencana.

Nurudin, N. (2007). Pengantar Komunikasi Massa. Depok: RajaGrafindo Persada.

Peran Media Massa Ubah Perilaku Masyarakat dalam Menyikapi Pandemi. (2020, June 2). Diakses dari https://covid19.go.id/p/berita/peran-media-massa-ubah-perilakumasyarakat-dalam-menyikapi-pandemi

Rahman, A. (2010). Kompetensi Wartawan Pada Surat Kabar Tribun Pekanbaru. Universitas Islam Negeri Sultan Syarif Kasim Riau.

Ramadhan, A. (2020, April 18). UPDATE: Tambah 15, Pasien Covid-19 Meninggal di Indonesia Ada 535. Diakses dari https://nasional.kompas.com/read/2020/04/18/15575031/updatetambah-15-pasien-covid-19-meninggal-di-indonesia-ada-535?page=all

Saragih, M. Y. (2016). Media Massa dan Jurnalisme: Kajian Pemaknaan antara Media Massa Cetak dan Jurnalistik. Jurnal Pengembangan Masyarakat, 3(3), 108-119.

Shoemaker, P. J., \& Vos, T. (2009). Gatekeeping theory. Abingdon: Routledge.

Triyaningsih, H. (2020). Efek Pemberitaan Media Massa Terhadap Persepsi Masyarakat Tentang Virus Corona (Studi Kasus; Masyarakat di Pamekasan). Meyarsa: Jurnal Ilmu Komunikasi Dan Dakwah, 1(1), 1-21.

Wildan, M. A., Saleh, A. M., \& Imron, M. A. (2020). Strategi Rekrutmen Dalam Peningkatan Kinerja Karyawan Media Pers Indonesia. IDEI: Jurnal Ekonomi \& Bisnis, 1(1). https:// doi.org/10.38076/ideijeb.v1i1.7 